\title{
The impact of night work on subjective reports of well-being: an exploratory study of health care workers from five nations
}

\author{
Donald I Tepasa, Janet L Barnes-Farrell ${ }^{b}$, Natalia Bobkoc, Frida M Fischer ${ }^{d}$, Irena Iskra- \\ Golec $^{e}$ and Ljiljana Kaliterna ${ }^{f}$
}

${ }^{a}$ Connecticut Transportation Institute. University of Connecticut. Storrs, USA. ${ }^{b}$ Department of Psychology. University of Connecticut. Storrs, USA. 'Institute of O ccupational Health. Kiev, U kraine. ${ }^{d}$ Faculdade de Saúde Pública. Universidade de São Paulo. São Paulo, SP, Brasil. eInstitute of Management. Jagiellonian University. Krakow, Poland. ${ }^{f}$ Ivo Pilar Institute of Social Sciences. Zagreb, Croatia

\section{Keywords}

Shift work. Night work. Health occupations. Work hours. Occupational health. Perception. Age factors. Fatigue. Stress.

\section{Descritores}

Trabalho em turnos. Trabalho noturno. Ocupações em saúde. Jornada de trabalho. Saúde ocupacional. Percepção. Fatores etários. Fadiga. Estresse.

\begin{abstract}
Objective

To carry out a survey data collection from health care workers in Brazil, Croatia, Poland, Ukraine and the USA with two primary goals: (1) to provide information about which aspects of well-being are most likely to need attention when shiftwork management solutions are being developed, and (2) to explore whether nations are likely to differ with respect to the impacts of night work on the well-being of workers involved in health care work.

Methods

The respondents from each nation were sorted into night worker and non-night worker groups. Worker perceptions of being physically tired, mentally tired, and tense at the end of the workday were examined. Subjective reports of perceived felt age were also studied. For each of these four dependent variables, an ANCOVA analysis was carried out. Hours worked per week, stability of weekly work schedule, and chronological age were the covariates for these analyses.

Results

The results clearly support the general proposal that nations differ significantly in worker perceptions of well-being. In addition, perceptions of physical and mental tiredness at the end of the workday were higher for night workers. For the perception of being physically tired at the end of a workday, the manner and degree to which the night shift impacts the workers varies by nation.

Conclusions

Additional research is needed to determine if the nation and work schedule differences observed are related to differences in job tasks, work schedule structure, off-the-job variables, and/or other worker demographic variables.
\end{abstract}

\section{Resumo}

\section{Objetivo}

Coletar dados de pesquisa de profissionais da saúde no Brasil, Croácia, Polônia, Ucrânia e Estados Unidos com duas metas principais: (1) proporcionar informações quanto a aspectos do bem-estar que mais provavelmente precisam de atenção durante a elaboração de soluções administrativas para os turnos de trabalho e (2) examinar a existência de possiveis diferenças entre os países quanto ao impacto do trabalho no bem-estar de profissionais da saúde.

Presented at the XVI International Symposium on Night and Shiftwork, N ovember 2003. Santos, SP, Brazil. Received on 15/3/2004. Approved on 27/9/2004. 


\begin{abstract}
Métodos
Os respondentes de cada um dos países estudados foram divididos em dois grupos de profissionais: período noturno e período não-noturno. Verificou-se a percepção dos profissionais quanto ao cansaço físico, cansaço mental e tensão ao final da jornada de trabalho. Relatos subjetivos sobre a percepção da idade sentida também foram estudados. Foi feita uma análise ANCOVA para cada uma destas quatro variáveis. Horas trabalhadas por semana, estabilidade do horário semanal de trabalho e idade cronológica foram as co-variáveis usadas nestas análises.

Resultados

Os resultados dão evidente respaldo à proposição geral de que há diferenças consideráveis da percepção de bem-estar entre os países. Além disso, a percepção de cansaço físico e cansaço mental ao final da jornada de trabalho é maior entre os profissionais do período noturno. Difere entre os países, a percepção do cansaço físico ao final da jornada de trabalho, a maneira e o grau do impacto do turno noturno para os profissionais de saúde.

Conclusões

Fazem-se necessários outros estudos para determinar se as diferenças observadas entre os países e esquemas de trabalho guardam relação com diferenças de funções no trabalho, estrutura dos horários de trabalho, variáveis externas ao trabalho elou outras variáveis demográficas dos profissionais.
\end{abstract}

\section{INTRODUCTION}

In the contemporary expanding global workplace, people are often required to make prompt work schedule decisions. ${ }^{11}$ Within this international climate, it is tempting to transfer strategies for measuring and managing shiftwork directly from one nation to another nation. However, there has been little shiftwork research specifically designed to confirm the general efficacy of efforts to transfer shiftwork knowledge from one nation to another. With regard to night shift work, a number of generic questions are appropriate. Does the impact of night work vary from nation to nation? Is the impact of night work modest or minimal in some nations? Should shiftwork management solutions be tailored to the characteristics of a specific nation?

Recent reviews of the literature on impacts of shiftwork provide evidence that working at night can be associated with negative outcomes for workers, their families, and the organizations for which they work, although the findings of empirical field studies regarding the impact of night work are not always consistent. ${ }^{6}$ Furthermore, it has been pointed out that some of the risks associated with working at night may be higher for women, particularly women with children at home. ${ }^{7}$ For this reason, occupations in which women form a large part of the workforce should be examined very closely with respect to the impact of night work.

One such occupational group is represented by health care workers. Healthcare workers in many na- tions are disproportionately female, and the nature of this work requires that a significant portion of the workforce carry out their jobs occasionally or exclusively at night. Empirical studies of health care workers' reactions to night and shiftwork have been carried out in several countries. They provide some evidence of the impact of night work on physical and psychological well-being, although it should be noted that most studies have provided data regarding reactions to night work within the context of a single nation. ${ }^{3,4,8,9,10}$ For example, in a longitudinal study of Australian student nurses, Bohle and Tilley reported a negative effect on psychological well-being when student nurses moved from a day shift to a night shift; they found that night work was a significant predictor of a variety of psychological symptoms. ${ }^{4}$

More recently, using data from one nation that was gathered as part of a five nation study, Kaliterna et $\mathrm{al}^{4}$ found that night shift workers in the health care professions reported being more physically tired at the end of their workday than did non-night workers. Although Kaliterna's study provides data indicating that night work is associated with some negative consequences for the well-being of health care workers in one nation, it does not address the question of whether this phenomenon is likely to be observed for workers in other nations who are employed in health care occupations.

The present report expands on Kaliterna's findings regarding the impact of night work on the well-being of health care workers by examining differences between night workers and non-night workers for the entire array of five nations in the database. We fo- 
cused on several self-report measures of wellbeing. Barnes-Farrell et $\mathrm{al}^{2}$ have published an analysis of this five nation database, but they did not examine the data with regard to the impact of night work. The present report is the first comparison of the data from each of the five nations with regard to night shift impact. We have two primary goals in this exploratory study: (1) to provide information about which aspects of well-being are most likely to need attention when shiftwork management solutions are being developed; and (2) to explore whether nations are likely to differ with respect to the impacts of night work on the well-being of workers involved in health care work.

Workers from Brazil, Croatia, Poland, Ukraine, and the United States participated in this study. By intentional design, these five nations represent a broad range of differences in culture, history, current economic status, geography, climate and political state. It is assumed that using these five nations increases the likelihood that differences between nations will be manifest in the data collected. Within each nation, data collection was limited to employed health care workers. Using this occupational category is a crude and practical effort to control and minimize between nation differences in work design, work demand, and training. Since many health care operations require around-the-clock services, using this occupational group also ensures that many of the participants are employed on the night shift. Furthermore, our focus on health care occupations assures a high representation of women among our night workers.

\section{METHODS}

\section{Participation}

A total of 865 health care workers from Brazil, Croatia, Poland, Ukraine, and the United States elected to participate in this survey. These are samples of convenience, and the names of individual workers are not included in the central data files. The central data files are only resident in the USA. In an effort to minimize distracting geopolitical discussion in this exploratory study, nation identity is coded in this report. Nations are identified consistently in the text (and all figures) by the letters A, B, C, D and E. Sample sizes for individual nations ranged from 132 to 250 .

Overall, $85 \%$ of the participants were female, with the proportion of female participants in individual national samples ranging from $69 \%$ to $100 \%$. Figure 1 shows the Mean reported chronological age and perceived personal age (felt age) of the respondents from each nation. Mean age for the full sample was 36.7 years ( $\mathrm{SD}=10.4$ years), with average chronological age for the five individual nations ranging from 32.4 years to 43.1 years. On average, felt age is less than chronological age within each of these five nations. This difference between chronological age and felt age is as it was reported in a previous paper. ${ }^{2}$ Participants were sorted into night worker and non-night worker groups on the basis of their answer to the item "Do you usually work at night?" This is the same criterion as used by Kaliterna. ${ }^{9}$ Overall, $35 \%$ of the participants were sorted into the night shift worker category; the proportion of participants classified as night shift workers ranged from $29 \%$ to $41 \%$ among individual national samples. Participants in the study reported working an average of 43.6 hours per week $(\mathrm{SD}=12.6$, range among national samples $=38.0$ to 54.7 hours per week), and $71 \%$ of participants reported that they usually work the same hours of the day each week (range among national samples, 59\% to $89 \%$ ).

\section{Survey measurement}

With input and consideration of workplace concerns relevant to the nations under study, the 62 item self-report "Survey of Health Care Professionals" was designed to assess a wide range of workplace variables and off-the-job activities. The survey was initially written in English, and it was then translated into the language of the other four participating nations. These translated surveys were then back-translated into English to ensure comparability of items across nations. The present report focuses on three self-report scales that have previously been demonstrated to be related to work schedules. ${ }^{5}$ For each of these three items, participants were asked to rate, on a 4-point scale, how physically tired, mentally_tired, or tense they felt at the end of the workday. The response 


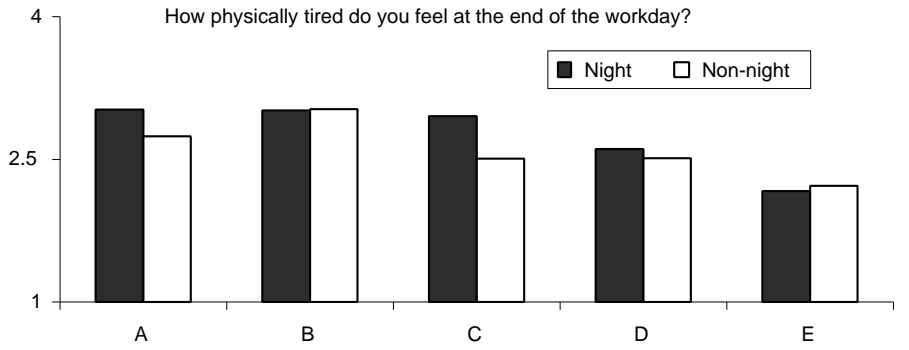

Figure 2 - Mean response to the physically tired variable.

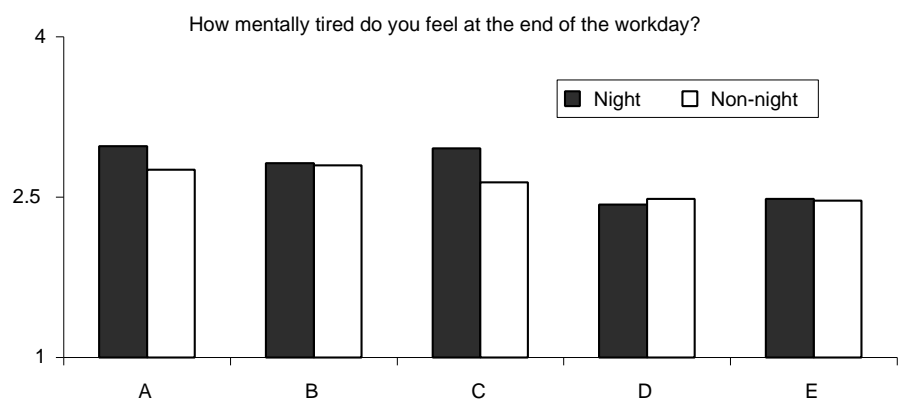

Figure 3 - Mean response to the mentally tired variable.

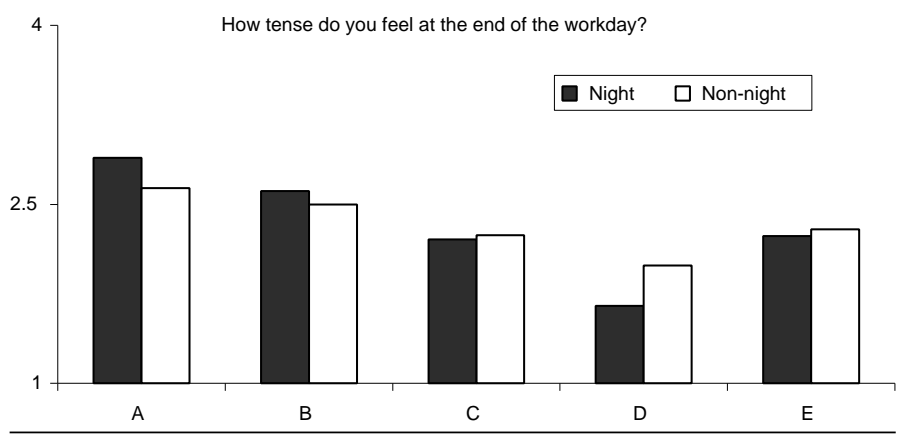

Figure 4 - Mean rewponse to the tense variable.

scale categories were: "not-at-all" (assigned a coding value of 1), "a little" (assigned a coding value of 2 ), "quite a bit" (assigned a coding value 3 ), and "extremely" (assigned a coding value of 4 ). This results in an assumed scale midpoint value of 2.5. A fourth item was a perceived personal age estimate (in years) which has been shown in previous research to be related to stress. ${ }^{1}$

\section{RESU LTS}

The same ANCOVA analysis was conducted for each of the four dependent variables. This was a $2 \times 5$ ANCOVA model with work schedule (night, non-night night workers) and nation (A, B, C, D, E) as independent variables. There were nation differences with regard to chronological age of survey participants and work schedule arrangements, such as number of hours worked and whether workers had similar schedules each week. In order to control for the effects of these variables on our dependent variables, items measuring chronological age, number of hours worked, and sameness of hours worked each week were included as covariates in all of our analyses. The Means shown in the following graphs have been adjusted for these three covariates. For all statistical tests, a $p=.05$ is considered to be a significant effect.

\section{Physically tired}

The dependent variable for this analysis was the participant response to this item: "On a normal workday, how physically tired do you feel at the end of the workday?" Figure 2 shows the adjusted Mean responses to this item for the night and non-night workers from each of the five nations. For this dependent variable, the differences for work schedule, nation, and the interaction between work schedule and nation are all significant.

\section{Mentally tired}

The dependent variable for this analysis was the participant response to this item: "On a normal workday, how mentally tired do you usually feel at the end of the workday?" Figure 3 shows the adjusted Mean responses to this item for the night and non-night workers from each of the five nations. For this dependent variable the work schedule and nation differences are significant, but the interaction is not significant.

\section{Tense}

The dependent variable for this analysis was the participant response to this item: "On a normal workday, how tense do you usually feel at the end of the workday?" Figure 4 shows the adjusted Mean responses to this item for the night and non-night workers from each of the five nations. For this dependent variable, nation differences are significant, but work schedule differences and the interaction are not significant.

\section{Felt age}

The dependent variable for this analysis was the participant response to this item: "(most of the time) How old do you feel?" answered in years. Figure 5 shows the adjusted Mean responses to this item for the night and non-night workers from each of the five nations. For this dependent variable, nation differences are significant, but work schedule differences and the interaction are not significant. 


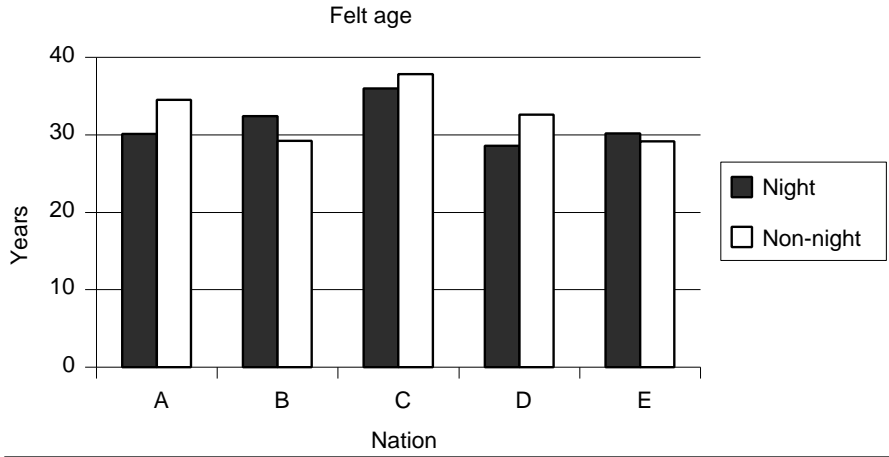

Figure 5 - Mean subjective felt age for each treatment group.

between work schedule and nation. This finding demonstrates that the impact of work schedule (night work) can vary from nation to nation on at least one dimension of wellbeing. For some nations, the impact of night work on this item is negative, and in other nations it is quite modest or minimal. The results for mentally tired and tense did not perfectly mirror those for physically tired. This supports the proposal that participants perceived and responded to these three items in distinct ways. In turn, these findings suggest that shiftwork solutions for nations

\section{DISCUSSION}

Overall, the results presented here consistently demonstrate that nations can vary in how health care workers perceive their well-being. All of the dependent variables that we examined differed significantly among nations, even after statistically controlling for some relevant demographic features of the workforce that were known to differ among the samples from the five participating nations - worker age, length of work week and stability of weekly work schedule. As a previous analysis of this database has shown, many items in this survey database also show significant effects for nation. ${ }^{2}$ Given these findings, it is reasonable to conclude that for the sample studied, nation differences are quite robust. Of course, nation differences may not be evident if one looked at a different mix of nations, another occupational group, or other variables. However, the clear demonstration that nation differences can and do occur reinforces the proposal that they should not be ignored. Given a global workplace where managers are frequently tempted to transfer methods from one nation to another, a very cautious approach to knowledge transfer is warranted.

Beyond the robust nation differences that were observed for all of our measures of worker well-being, two of the four dependent variables that we studied showed work schedule differences. In general, health care workers who primarily worked at night reported feeling more physically and mentally tired at the end of the workday. Furthermore, these effects cannot be attributed to differences in the ages of night and non-night workers, differences in the variability of their work schedules, or differences in the average work weeks (in hours) for health care workers who usually work the night shift and those who usually work non-night shifts. This provides additional evidence that working the night shift has implications for the well-being of health care workers.

In addition, reports of being physically tired at the end of the workday showed a significant interaction should consider many variables and be tailored to the characteristics of a specific nation.

Worker age is not a simple demographic variable. ${ }^{12}$ Just as chronological age varies from nation to nation, subjective felt age shows a significant nation effect. It is important to keep in mind that chronological age was statistically controlled in these analyses. As such, the national differences in felt age that are reported here are not a simple reflection of differences in the chronological ages of the five national samples. Although felt age has been associated with stressful working conditions in prior research, ${ }^{1}$ no demonstrable relation of felt age to work schedule (night work) is evident in the database studied. In particular, the notion that night workers feel older than non-night workers is not supported by the present study. On the other hand, it is important to remember that workers in general and across nations do feel younger than they are. ${ }^{2}$ Could it be that night work only modestly moderates or suppresses worker felt age perceptions? In any case, different felt age results might be obtained if the range of participant age was expanded.

One might take the position that the nation and work schedule differences found in the present study are simply artifacts related to workplace differences and sampling error. That is, the study results are mainly an artifact produced by using samples of convenience. For example, this interpretation might argue that some or all of the observed significant differences in the physically tired variable (for example) would disappear if the worker groups were matched for job tasks performed, work schedule design employed, and/or demographic variables. The present study attempted to control for many of these possibilities with the three statistical covariates used, and by limiting the participants to an occupational group. In any case, one might also argue that the results obtained in the present study are common, realistic benchmarks, and represent usual job stresses and strains in the nations studied.

Although the total sample size for the present study 
is fairly large and all individual national samples were well in excess of 100 , this is nonetheless an exploratory study based on convenience samples. Biasing factors within individual samples may have contributed to some of the national differences that we observed and may limit the generalizability of the night work effects that we observed (as well as those that we failed to observe). This work must be supplemented with studies that are able to draw data from large population samples in order to make strong comparisons among the variables of interest.

Additional research should aim at uncovering the variables that produce the nation by work schedule interactions demonstrated in the present study. For example, nations differ fairly dramatically with respect to working hour regulations and with respect to shift systems (e.g., the typical length of individual shifts and the typical break between work periods). This may affect the extent to which night work impacts various aspects of worker well-being. Likewise, nations differ with respect to the amount of public and social support they provide to night workers who have family responsibilities. It is possible that this represents an-

\section{REFEREN CES}

1. Barnes-Farrell J, Piotrowski M. Discrepancies between chronological age and personal age as a reflection of unrelieved worker stress. Work Stress 1991:5:177-87.

2. Barnes-Farrell JL, Rumery SM, Swody CA. How do concepts of age relate to work and off-the-job stresses and strains? A field study of health care workers in five nations. Exp Aging Res 2002;28:97-8.

3. Bohle P, Tilley AJ. Early experience of shiftwork: Influences on attitudes. J Occup Organ Psychol 1998;71:61-79.

4. Bohle P, Tilley AJ. The impact of night work on psychological well-being. Ergonomics 1989;32:1089-99.

5. Carvalhais AB, Tepas DI, Paley MJ. An evaluation of a coast guard "live-aboard" concept: can crews adapt to a restricted living and operational environment? Proceedings of the $38^{\text {th }}$ Annual Meeting of Human Factors and Ergonomics Society; 1994 O ct 24-28; Nashville, TN, USA. Santa Monica, CA: Human Factors and Ergonomics Society; 1994. p. 873-77. other important national context variable that contributes to the magnitude of the effect of night work on worker well-being. Although we made a crude attempt to control for job demands in our study by limiting ourselves to a reasonably homogeneous occupational group, there are nonetheless differences among nations with respect to the design and demands of health care work that may similarly influence whether, and how much, night work influences various aspects of wellbeing. We encourage other researchers to give serious thought to the important similarities and differences in organizational and socioeconomic conditions under which night work is carried out in different nations, and to include such variables in future studies of night work. This will help to develop clearer notions about whether and when shiftwork strategies developed to manage night work in a particular national setting are likely to transfer effectively to other national settings. Multi-nation studies are difficult to do, but they are important in a global workplace. Multination research appears to offer investigators a unique opportunity to demonstrate and evaluate the interaction of off-the-job variables with workplace variables and work schedules.
6. Costa G. Factors influencing health of workers and tolerance to shift work. Theor Issues Ergon Sci 2003;4:263-88

7. Costa G. The impact of shift and night work on health Appl Ergon 1996;27:9-16.

8. Estryn-Behar M, Gadbois C, Peigne F, Masson A LeGall V. Impact of nightshifts on male and female hospital staff. In: Costa G, Cesana GC, Kogi K, Wedderburn A, editors. Shiftwork: health, sleep and performance. Frankfurt: Peter Lang; 1990. p. 89-94.

9. Kaliterna L, Prizmi Larson Z, Brklja I. Beliefs about age and physical demands of work in shiftworkers. Hum Ergol 2001;30:391-6.

10. Smith SS, Robie C, Folkard S, Barton J, Macdonald I, Smith $L$ et al. A process model of shiftwork and health. J Occup Health Psychol 1999;4:207-18.

11. Tepas DI. Workware decision support systems: a comprehensive methodological approach to workscheduling problems. Theor Issues Ergon Sc 2003:4:319-26.

12. Tepas DI, Barnes-Farrell JL. Is worker age a simple demographic variable? Exp Aging Res 2002;28:1-5. 